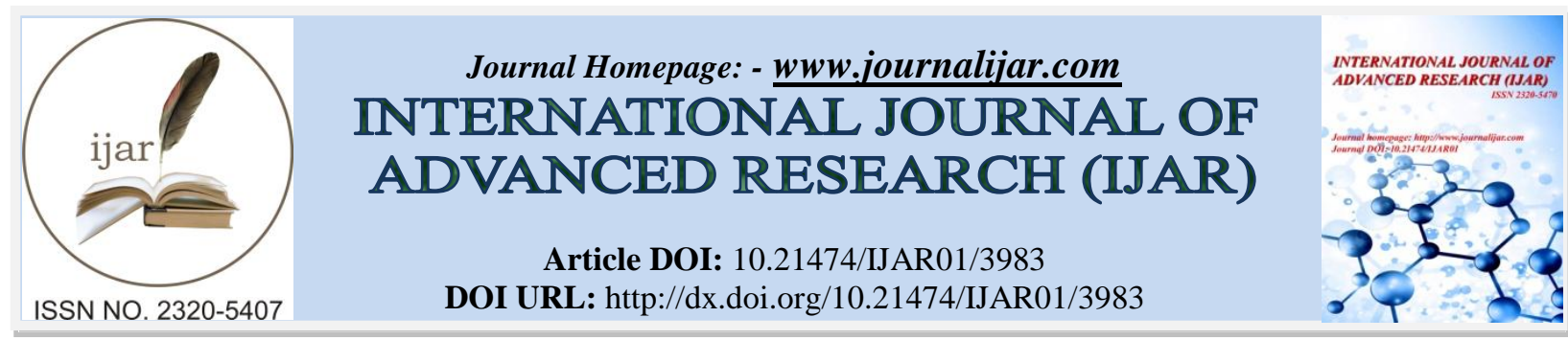

RESEARCH ARTICLE

\title{
REPRESENTING THE MICROCOSM IN THE MACROCOSM: THE VISIONARY ASPIRATIONS OF IDENTITY IN ORHAN PAMUK'S THE WHITE CASTLE.
}

S.P.Anuja ${ }^{1}$, Dr. N. Asharudeen ${ }^{2}$ and Dr. K. Pramila ${ }^{3}$.

1. Research Scholar, Dept. of English, Karpagam University, Karpagam Academy of Higher Education, Coimbatore.

2. Assistant Professor, Dept. of English, Karpagam University, Karpagam Academy of Higher Education, Coimbatore.

3. Associate Professor, Head, Dept. of English, PSG itech, Coimbatore.

\section{Manuscript Info}

Manuscript History

Received: 23 February 2017

Final Accepted: 12 March 2017

Published: April 2017

Key words:-

Polarized, Eurocentric, Connotation, European dream, Microcosm, Macrocosm

\section{Abstract}

The concept of identity and its Universal appeal takes center stage in "The White Castle". The protagonists struggle in taking on the life which they desire, its relevance and how it exhibits the real problem in a nutshell has a great magnitude. Hoja flees to Italy to take the place of the scholar. The scholar is left to take the place of Hoja which he does not aspire for. Though one of the protagonists has not got the choice to make, the other succeeds in gaining it. This problem which has a universal significance represents the macrocosm which is portrayed through a small parameter of microcosm with a parallel portrayal of the East and West clash.

Copy Right, IJAR, 2017,. All rights reserved.

\section{Introduction:-}

Ferit Orhan Pamuk, a remarkable novelist of Turkey has brought the cartouche of its cultural and social panorama through postmodern narration. His works have a novel combination of characterisation established within a multidimensional plot. Many of his writing evoke the conscience of the reader pondering over literary maze with the grip of self realization and doppelganger ideology. The plot of his novels exhibit the veridical perception of Turkey's corporeality. Pamuk, with his painstaking effort has achieved a great feat through his contribution to literature.

The story is set in the seventeenth century Turkey and narrated from a historian's point of view later takes the stand from the protagonists' point of view. The script has gathered layers of dust along with piles of documents in a government archive where it had rested for ages together. Faruk Darvinoglu begins the narration with a Venetian fleet being captured by Turkish pirates. Many passengers in the fleet develop sea sickness and other infestations during the voyage. An Italian scholar on his way to Maples is also one among the captives. He has a good understanding on Western science and medicine with which he is able to cure the illness of many. He is sold as a slave to the Pasha in Istanbul and later to an important member in court dealings, named Hoja. "I had seen someone I must be; and now I thought he too must be someone like me. The two of us were one person" (71).

The scholar attends to Hoja's official works. Hoja comes to know that the scholar has cured many in the prison and has earned a good reputation. The pasha learns that the scholar and Hoja have a striking resemblance and is also able to differentiate between them. Hoja learns Western Engineering and medicine from the scholar. Hoja, filled with 
pseudo scientific beliefs and ideologies commands the scholar to teach everything he knows. A plague breaks out in Istanbul and Hoja is commissioned to find a cure and he seeks the help of the scholar. Cats are deployed and the plague is brought to a halt. Hoja is promoted as the imperial astrologer after acting according to what the scholar had said. "I already sensed then that I would later adopt his manner and his life-story as my own. There was something in his language and his turn of mind that I loved and wanted to master" (53).

The White Castle is a profound story on the ideological clash of the East and the West. When the Pasha commissions Hoja for official work, he swaps identity and insists the scholar to carry out all his instructions. Later he gathers all that has been told and with the scholar's plan and strategies he implements his plans taking all the credits for himself and letting the scholar aloof. In a span of eleven years, Hoja learns everything about the scholar. Hoja is highly opinionated and contemplates on taking the place and identity of the scholar.

Hoja is the symbolic representation of the West and the Italian scholar is the personification of an ordinary Tukish layman unaware of the changes happening in the political front. The novel plods into the political and personal spheres of Hoja bringing to light Hoja's aim on gaining and establishing identity through the scholar. Secondly on capturing the gleaming white castle of the poles which is his vested political interest Hoja has clear focus on both his aims apart from which he had other plans too. If the Turks win the war, he would continue his political life with the fame that he has won or he would flee to Italy to take the place of the scholar and live with his identity for the rest of his life if at all the war comes to an untoward end.

The name of the scholar is not mentioned throughout the novel. Both the protagonists knew everything about each other which the reader is given to believe that are inseparable. As Hoja becomes the Freudian father, he domineers over the scholar in everything. The didactic relationship of a master and slave has the influence of the Freudian father complex. The strong physical resemblance is also an important factor in cementing their relationship. "Hoja would explain that on the throne that on the throne he would remain forever young, but only by making weapons superior to those of our ever vigilant enemies could he be safe from their treachery" (92).

Hoja gains knowledge of the West and strong political hold with the help of the scholar. His inner craving for absolute power takes him to an extent where he convinces the Sultan on constructing a mighty war weapon to combat the Poles and establish themselves as the supreme ruling power in the West. He designs the war machine on his own which flounders in the swamp and war becomes a disaster. For the scholar, it brings a traumatic experience as Hoja who is prepared to face this situation flees to Italy with the scholar's clothes severing ties with the scholar, forever.

The inability to act tough against his master is pestering the scholar's conscience which is equated to inaction against the European stand. It has become a stereotypical mindset of Turkey that Europe is more powerful and they are inferior. Turkey's hope to attain the European dream has become feebler day by day. It is not the White Castle that is lost but also the very identity of the scholar. The White Castle also signifies identity. The fear of losing identity and the hopelessness to reach his motherland brings in a state of shock and defeat to the scholar who finally forces himself to take what is left behind and move ahead in life."This was a fantasy which had never been dreamt at all: he had us as brothers! He'd found it appropriate to play the role of elder to me while I listened obediently to his scientific lectures" (66).

The scholar does not surrender to Pasha's order on accepting Islam. Though threatened repeatedly he never admits. Turkey comprises of people with Western and Eastern mindset which leads to conflict. The scholar is victimized by politics. He and Hoja lived like brothers who shared a strange bond and took the role of the other. The ideology of doppelganger takes both of them in for a toll. One achieves what he wants and the other is left to fill his void on his own. The power equation does not work out for Turkey.

The White Castle has a global connotation. The struggle of the scholar which is portrayed in a small parameter has a greater implication. He is the representation of a microcosm. Microcosm means encapsulating something in miniature which has the characteristics of something much larger. The whole of a complex structure, like the world or the universe, contrasted with a small or representative part of it, is called a macrocosm. The 'scholar' represents the real face of identity crisis through the perspective of microcosm in a macrocosm. The problem has a universal appeal which is presented in a nutshell. 
The scholar has become a symbol signifying the reality of the masses. An individual whose problem has become a pertinent issue in the world today is what represents the microcosm and to the world in which the individual struggles indicates the macrocosm. Similarly, Hoja is able to foresee himself in the place of the scholar has made all his aspirations come true. Both the protagonists achieve what seems befitting for them as individuals. Their story discovers the inevitable issue of identity crisis; one is able to achieve his visionary aspirations whereas the other doesn't. Hence the scholar and Hoja represent the microcosmic and macrocosmic visions respectively in which Hoja attains what he aimed whereas the scholar's desire to visit his homeland remains dormant.

\section{Works Cited:-}

1. Pamuk, Orhan. Istanbul: Memories and the City, Translated by Maureen Freely. New York: Alfred A.Knopf, 2005.

2. ---. Other Colour : Essays and Story, Vintage International, November 2008.

3. ---. The Naïve and the Sentimental Novelist Vintage International, November 2011.

4. ---. The White Castle, Translated by Victoria Holbrook. New York: Vintage International 1998.

5. ---.What Our Minds Do When We Read Novels: Penguin Specials, Penguin Books Limited, 2012. 